\title{
Pica, a Little-Known Condition in Dentistry. Case Report
}

\author{
Pica, una Condición Poco Conocida en Odontología. Reporte de un Caso
}

\author{
Sebastián Lavín-Niño de Zepeda
}

\begin{abstract}
LAVÍN-NIÑO DE ZEPEDA, S. Pica, a little-known condition in dentistry. Case report. Int. J. Odontostomat., 13(2):195-197, 2019.

ABSTRACT: Pica is a condition associated with the chronic, compulsive consumption of a particular substance or material that is not considered food. Culturally it is not accepted by society and its nutritional value is non-existent. When this behavior is repeated consistently for more than one month, it is considered to be Pica. This eating disorder does not have a clear etiology, but is associated with; orality in children, psychotic disorders, nutritional deficiencies, psychosocial problems, autism, family problems, OCD, stress, abuse, family separations and other traumatic events. In order to detect it, it is necessary to perform a correct anamnesis, clinical examination, radiographic examination, complementary examinations such as blood count, as well as a relationship of trust between the dentist and the patient are necessary. All of them will be able to guide us and make us come out of suspicion that this harmful behavior exists, since patients often hide it.
\end{abstract}

KEY WORDS: itching, anemia, dental attrition, lithophagy.

\section{INTRODUCTION}

Pica is considered a multifactorial condition and is generally associated with people of low socioeconomic status and/or intellectual disability (Golden et al., 2012). Despite this, Pica is present in both men and women of all ages and social groups, with a greater presence in young children and pregnant women (Chowdhury \& Basu, 2002).

In most cases, the sense of satisfaction with the taste or texture of the substance generates a degree of dependence that can affect the patient's health to varying degrees, from dental and gingival problems to anemia and obstruction of the gastrointestinal system. Pica can affect oral tissues in different ways, whether they are hard or soft tissues of the mouth, their functionality and aesthetics (Viguria Padilla \& Miján de la Torre, 2006). We must pay special attention to unusual wear or loss of dental tissue, abrasions, erosion, dental staining, periodontal diseases, halitosis, and poor oral hygiene and fractured restorations, among others.

In some patients we may find that polyphagic behavior is present, corresponding to the consumption of more than one non-nutritive substance during the same period (Giraldo, 2002).
Although it can occur in healthy patients, Pica is considered a mental disorder and in many cases is associated with different types of mental deficiencies, low blood iron levels or anemia (Barker, 2005). However, treatment that combines social interaction, safe environment design, attentive social care, and productive involvement activities in patients with some degree of delay can help, as therapy, in behavior change. These methods can reduce maladaptive behaviors and increase adaptive behaviors, achieving more proactive than reactive attitudes to this bad habit (Rasaratnam, 2014).

\section{CASE REPORT}

Female, 77 years old. ASA II lives in the coastal area of Atacama, Chile. She received and Oral evaluation consultation. In her anamnesis, it is noted that she is lucid and very aware of her oral damage, but she acknowledges that it is not one of her priorities to solve this problem. She is accompanied by family members and not by self-interest.

It is noted loss of vertical dimension, partial toothless with dental attrition zones. After gaining the 
patient's trust, she reports that for 40 years she chewed and swallowed white beach shells (Fisurella Sp.) kept them in her wallet, and hid them in the flowerpot inside her house (Figs. 1 and 2).

Its intake is daily and several times a day. This mental disorder called Pica is subdivided in relation to the substance consumed, in this case Lithophagy, which includes the consumption of stones and similar substances. Other known classifications of this condition are coprophagy (feces), trichophagy (hair), pagophagy (ice), geophagy (soil), etc.

The hedonic consumption of these shells gives her a satisfaction that she considers a real addiction, recognizing that the texture of chewing them generates more pleasure than their taste, discarding other characteristics such as smell and color.

She is referred to a doctor - internist to evaluate her general medical condition and hemoglobin (HB), serum ferritin, irregular abdominal pain and constipation levels, plus a psychological evaluation.

After more than a year of follow-up, this patient decides not to change her condition or seek help, and also discards the possibility of improving her oral health and aesthetics.

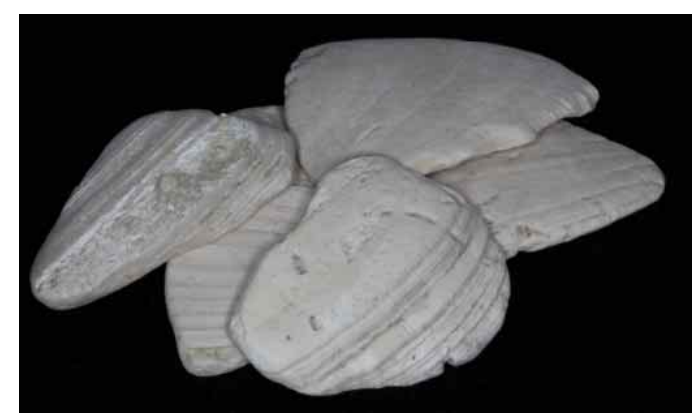

Fig. 1. Shell (Fisurella Sp.). Atacama, Chile.

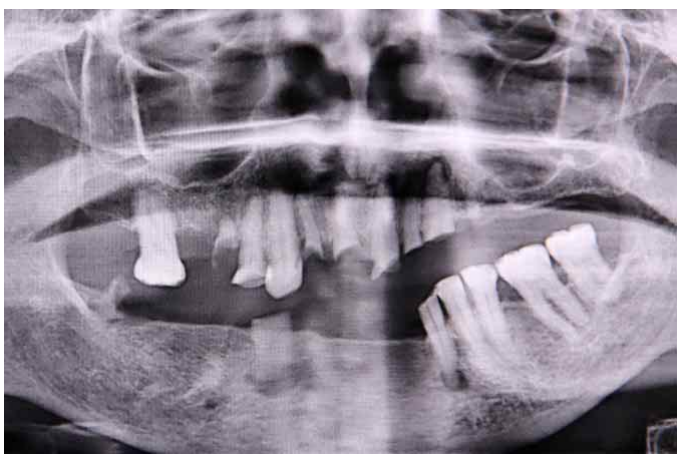

Fig. 2. Attrition and unusual pattern wear.

\section{DISCUSSION}

The consumption of sea shells (Fisurella.Sp.) can, like geophagy, reduce the bioavailability of some nutrients, as well as increase the possibility of infections and parasites (Dougall \& Fiske, 2008).

Multiple substances are considered inedible substances of this disorder, more than 29 , among which are usually found: ice, fabrics, ropes, clothing, soil, plastics, metals, paint, grass, feces, tobacco, hair, matches, stones, among others.

Dental complications will depend on the type of material and the frequency with which it is consumed, and may generate abrasions, erosion, dental staining, periodontal diseases, halitosis, poor oral hygiene, fractured restorations, among others (Swamy \& Dewang, 2011).

A blood count would be of great help in evaluating serum ferritin levels and iron-deficiency anemia (Gulia et al., 2007) due to many cases of Pica is related with iron deficiency anemia and a decrease in zinc and calcium.

\section{CONCLUSIONS}

The importance of a correct proximal anamnesis, correct clinical examination of the mouth and the detection of signs compatible with this condition are necessary for each patient. By means of the examination we can determine characteristics that could indicate some type of Pica and its detection and also the correct derivation and corresponding tests.

We must be attentive to the signs and symptoms that the patient relates to us, since this is a condition usually hidden by these patients.

A correct restorative treatment should be planned considering this condition and assigning it a correct prognosis.

The evaluation of this condition in public health is very important, since it is little studied and there are few reports on its real prevalence. It is essential to give it the clinical importance it deserves.

A patient with untreated Pica faces a number of health risks: wear to the teeth, gingivitis, dental fractures, 
intestinal and esophageal obstruction, parasitic infections, quadriparesis, rhabdomyolysis, hypocalcemia, toxoplasmosis, toxocariasis, metabolic disorders, mercury poisoning, intestinal obstruction and possible surgical treatments, and in the most serious cases, death. Mortality and morbidity are not studied, but would be associated with the type of substance and its frequency.

In most cases these patients hide their condition and isolate themselves (Rasaratnam). The support of a tutor is very important in the management of Pica, even when there is no clear treatment protocol, psychological and family support is very important.

Pica is an activity that patients generally perform secretly, hindering diagnosis and subsequent treatment, since this habit is not mentioned to their dentists and doctors, which aggravates and deepens this problem and causes it not to be treated correctly.

A timely diagnosis can help our patients in a systemic way and in the prevention of oral pathologies. It is especially important to detect it early in pregnant and/ or nursing women who acquire this bad habit, which corresponds to $20 \%$ of the cases studied.

The coordination of dentists, physicians and the family of patients are key to the detection and treatment of this disease, as well as a correct anamnesis. This condition should not be underestimated by the dentist.

LAVÍN-NIÑO DE ZEPEDA, S Pica, una condición poco conocida en odontología. Reporte de un caso. Int. J. Odontostomat., 13(2):195-197, 2019.

RESUMEN: Pica es una condición asociada al consumo compulsivo y crónico de alguna sustancia o material en particular, que no es considerada alimento. Culturalmente no es aceptado por la sociedad y su valor nutricional es inexistente. Cuando esta conducta se repite consiste-ntemente durante más de un mes, se considera como Pica. Este desorden de comportamiento alimenticio no tiene una etiología clara, pero se asocia a la oralidad en niños, trastornos psicóticos, deficiencias nutricionales, problemas psicosociales, autismo, problemas familiares, TOC, estrés, abuso, separaciones familiares y otros eventos traumáticos. Para detectarla, es necesaria una correcta anamnesis, examen clínico, radiográfico, exámenes complementarios como hemograma, además de una relación de confianza rapport odontólogo- paciente. El conjunto de ellos nos podrán guiar y salir de sospecha que esta conducta dañina existe, ya que los pacientes muchas veces lo esconden.

PALABRAS CLAVE: pica, anemia, atrición dental, litofagia

\section{REFERENCES}

Barker, D. Tooth wear as a result of pica. Br. Dent. J., 199(5):271-3, 2005.

Chowdhury, A. N. \& Basu, S. 'Impulsive pica': a new diagnostic category? Indian J. Psychiatry, 44(4):372-4, 2002.

Dougall, A. \& Fiske, J. Access to special care dentistry, part 6. Special care dentistry services for young people. Brit. Dent. J., 205(5):235-49, 2008.

Giraldo, B. Uso de técnicas no aversivas para el tratamiento de la pica en un adulto con retraso mental. Univ. Psychol., 1(2):35-8, 2002.

Golden, C. D.; Rasolofoniaina, B. J.; Benjamin, R. \& Young, S. L. Pica and amylophagy are common among Malagasy men, women and children. PLoS One, 7(10):e47129, 2012.

Gulia, J.; Yadav, S.; Rattan, K. \& Hooda, A. Complications of pica: case report and review of literature. Internet J. Head Neck Surg., 2(2), 2007.

Rasaratnam, L. Pica habit amylophagia - A case report. Int. J. Dent. Clin., 6(1):14-5, 2014.

Swamy, N. \& Dewang, D. Pica disorder (Geophagia): a case report. Int. J. Dent., 3(4):70-2, 2011.

Viguria Padilla, F. \& Miján de la Torre, A. La pica: retrato de una entidad clínica poco conocida. Nutr. Hosp., 21(5):557-66, 2006.

Corresponding author:

Dr. Sebastian Lavin N.

Odontostomatology. Private practice OPH Dental Clinic.

El Pino 524, casa K.

Copiapó

CHILE

Email: slavin@ophdental.cl

Received: 09-10-2018

Accepted: 01-02-2019 